\title{
Implementasi Perangkat Pembelajaran Berbasis Masalah Pada Penataan Sanggul Up Style Untuk Meningkatkan Hasil Belajar Mahasiswa Di Universitas PGRI Adi Buana Surabaya
}

\author{
Vony F.S Hartini Hippj \\ Fakultas Keguruan dan Ilmu Pendidikan Konsentrasi Tata Rias \\ Universitas PGRI Adi Buana Surabaya. \\ email: vonnyhippy@yahoo.com
}

\begin{abstract}
Developments in science and technology requires qualified human resources, able to develop and master the science technology through learning activities that can improve student learning outcomes in the cognitive, affective and psychomotor domains which automatically takes the role of tools and learning models. One type of learning model that can meet the needs for human resources capable of developing science and technology is a learning model based on the problem. Research design used in this research is the development of research design pattern and post-test one group pretest design. In this study the development of statistical hypothesis test results obtained using a sign test grades count $\geq h$ table. Mastery learning outcomes of students in each school with a learning model based on the problem gained mastery of $79.98 \%$ at class experimental and $76.69 \%$ at class control in adibuana university of Surabaya with KKM value by $70 \%$. Completeness of the results obtained it can be concluded from the results of the implementation of the development of a learning device based on the competency issue bun up styles to improve student learning outcomes well.
\end{abstract}

Keywords: Learning tool, Problem based instruction, Mastery learning

\section{PENDAHULUAN}

Perkembangan ilmu pengetahuan dan teknologi memerlukan sumber daya manusia yang berkualitas. Sumber daya manusia yang dibutuhkan adalah manusia yang mampu mengembangkan ilmu pengetahuan dan menguasai teknologi melalui kegiatan pengajaran. Hal ini tentunya sangat berkaitan dengan pendidikan.

Pendidikan merupakan usaha untuk menumbuh kembangkan potensi sumber daya manusia (SDM). Adapun pengertian pendidikan menurut Nursalim, dkk (2007:2) "Pendidikan pada sistem pendidikan nasional adalah usaha sadar untuk menyiapkan peserta didik melalui kegiatan bimbingan, pengajaran atau latihan dan peranannya di masa yang akan datang ".Pendidikan yang baik tidak hanya mempersiapkan para mahasiswa untuk suatu profesi atau jabatan, melainkan juga untuk mengembangkan kemampuan menyelesaikan masalah dalam kehidupan sehari-hari. Demi kelancaran dalam suatu proses pendidikan, diperlukan suatu kurikulum. Kurikulum tingkat satuan pendidikan (KTSP) pada tingkat SMK khusus Tata Kecantikan memiliki banyak kompetensi di dalamnya, salah satunya kurikulum pada kompetensi menata sanggul up style.
Bertolak dari masalah di atas maka peneliti ingin menggali kreatifitas mahasiswa yang diwujudkan dalam bentuk-bentuk penataan yang modern atau yang sedang digemari oleh pasar/konsumen dengan menggubah model pembelajaran yang diterapkan. Model pembelajaran yang ingin peneliti terapkan adalah model pembelajaran berbasis masalah. Pemilihan materi didasarkan pada pertimbangan bahwa materi tersebut berkaitan dengan keterampilan yang diperlukan oleh industri, sehingga memudahkan pemilihan konstektual yang digunakan sebagai langkah awal dalam pembelajaran berbasis masalah yang terkait dengan materi penataan sanggul up style.

Penataan dalam arti sempit memiliki pengertian suatu tindakan memperindah bentuk rambut sebagai tahap akhir proses penataan rambut. Penataan sanggul up style adalah suatu tindakan memperindah bentuk penataan rambut pada bagian belakang (back), bagian atas (top), dan bagian depan (front)dengan menambahkan rambut palsu dari hair piece, cemara gepeng atau lungseng sesuai trend dan keinginan. Secara umum penataan sanggul up style disebut sebagai penataan sanggul modern yang terbagi dalam 3 pola penataan, yaitu: (a) Pola penataan back style, (b) Pola penataan top style, (c) Pola penataan front style. 

up style:

Berikut penjelasan tentang pola penataan sanggul

Pola penataan back style adalah pola penataan yang dilakukan pada bagian belakang atau tengkuk, tepatnya mulai daun telinga atas hingga garis pertumbuhan rambut bagian bawah. Pola penataan ini biasanya diaplikasikan pada kesempatan memperingati hari-hari nasional dengan busana nasional atau resmi.

Pola penataan top style adalah pola penataan yang difokuskan pada bagian puncak kepala. Pola penataan ini bertujuan memberikan kesan tinggi bagi pengguna dan mewah, sehingga cocok digunakan pada model yang memiliki bentuk fisik yang tidak terlalu tinggi dengan bentuk wajah yang bulat. Bentuk sanggul ini biasanya diaplikasikan pada pengantin eropa atau bridal.

Pola penataan front style yang difokuskan pada bagian depan. Pola penataan ini biasanya diaplikasikan pada tema dramatis, futuristik dan retro. Hhasil penataan memiliki ciri utama yakni melebihi garis pertumbuhan rambut bagian depan tepatnya melebihi dahi namun tidak sampai menutupi alis mata.

\section{METODE}

Berdasarkan tujuannya, penelitian ini merupakan penelitian dengan kategori pengembangan. Penelitian pengembangan yang dimaksudkan adalah penelitian yang dilakukan untuk menghasilkan perangkat pembelajaran sanggul up style untuk SMK tata kecantikan yang berorientasi pada model pembelajaran berdasarkan masalah. Penelitian ini diawali dengan pengembangan perangkat pembelajaran berupa Rencana Pelaksanaan Pembelajaran (RPP), Lembar Kerja Mahasiswa (LKS), dan Tes Hasil Belajar (THB).

Adapun pengembangan perangkat mengacu pada model 4-D, yang dikemukakan oleh Thiagarajan, Semmel (1974:5). Penelitian ini terdiri dari empat tahap, yaitu (1) Tahap persiapan, (2) Tahap pelaksanaan, (3) Tahap pengembangan, (4) Tahap penyebaran. Dengan rancangan penelitian one group pretest and posttes design.

Instrumen atau alat penelitian adalah sarana yang digunakan peneliti untuk memperoleh atau mengumpulkan data. Instrumen yang peneliti gunakan dalam hal ini yakni instrumen lembar validasi dan instrumen lembar pengamatan. Mengacu pada masalah yang akan diteliti, maka teknik pengumpulan data yang digunakan dalam penelitian ini meliputi analisis data hasil validasi dan analisis data hasil pengamatan.
Untuk melakukan teknik analisis data mengacu pada berbagai buku referensi statistik penelitian sebagai berikut:

Analisis data hasil validasi. Hasil validasi dikumpulkan setelah validator memberikan penilaian terhadap perangkat pembelajaran serta instrumen penelitian yang telah dikembangkan peneliti. Penilaian terdiri dari 4 kategori, yaitu kurang baik (nilai 1), cukup baik (nilai 2), baik (nilai 3), sangat baik (nilai 4). Berbagai masukan, komentar, dan saran-saran dari validator dijadikan pedoman dalam melakukan revisi terhadap perangkat pembelajaran dan instrumen penelitian yang dikembangkan.

Analisis data hasil pengamatan pengelolaan kelas. Pengambilan datanya dilakukan oleh dua orang pengamat yakni satu mahamahasiswa S1 dan satu guru mitra. Data pengelolaan pembelajaran dianalisis dengan cara menghitung rata-rata skor penilaian oleh dua orang pengamat menggunakan interval skor 1 sampai dengan 4 . Dengan kriterian sebagai berikut: $1=$ terlaksana, kurang sesuai, tidak sistematis dan tidak tepat, $2=$ terlaksana,sesuai, tidak sistematis dan tidak tepat, $3=$ terlaksana, sesuai, sistematis dan kurang tepat, $4=$ terlaksana, sesuai, sistematis dan tepat.

Analisis data aktivitas mahasiswa. Teknik pengambilan terhadap aktivitas mahasiswa selama pembelajaran adalah dengan cara memberikan tanda $\checkmark$ pada nomor-nomor kategori aktivitas mahasiswa yang muncul sepanjang kegiatan pembelajaran berlangsung dengan selang waktu 3 menit.

Teknik yang digunakan untuk menganalisis data aktivitas mahasiswa yang diamati, menggunakan teknik persentase (\%), yaitu banyaknya frekuensi aktifitas yang muncul dibagi keseluruhan aktivitas dikali $100 \%$. Persamaannya dapat dituliskan sebagai berikut:

Analisis data respons mahasiswa. Respon dimaksudkan untuk menjaring pendapat mahasiswa terhadap proses pembelajaran, LKS yang telah dikerjakannya, serta buku mahasiswa yang telah dikaji secara cermat untuk membantu menguasai materi pembelajaran.

Data yang diperoleh dari pengisian angket yang disebarkan setelah kegiatan pembelajaran dianalisis persetasenya secara kuantitatif, yakni banyaknya respon untuk setiap mahasiswa yang diperoleh melalui angket tersebut dianalisis dengan menggunakan statistik deskriptif dengan persentase sesuai rumus berikut ini. 
Analisis data hasil belajar. Data hasil belajar mahasiswa menggunakan pre-test dan post test, berikut analisis pada instrument pre test dan post test:

Ketuntasan Belajar. Ketuntasan belajar dianalisis untuk mendapatkan persentase ketuntasan hasil belajar mahasiswa. Hasil belajar mahasiswa dikatakan tuntas atau tidak jika seorang mahasiswa mencapai ketuntasan hasil belajar $\geq 75 \%$ dan suatu kelas dikatakan tuntas bila di dalam kelas telah mencapai $\geq 85 \%$ mahasiswa telah mencapai ketuntasan belajar. Guna mendapatkan hasil ketuntasan di atas maka peneliti menggunakan rumus persamaan di bawah ini (Trianto, 2009:241).

Uji Normalitas. Setelah dilakukan uji coba dan diketahui bahwa instrumen penelitian sudah valid dan reliabel, maka peneliti melakukan uji normalitas dan homogenitas terhadap subjek penelitian yang akan dijadikan sebagai obyek penelitian. Untuk menguji normalitas digunakan rumus Chi kuadrat atau Chi Square $\left(\mathrm{X}^{2}\right)$ sebagai berikut:

Uji Hipotesis. Uji hipotesis yang peneliti gunakan dalam penelitian ini adalah uji tanda. Uji tanda sering digunakan dalam penelitian yang ingin membandingkan hasil dua perlakuan. Uji tanda akan dilakukan berdasarkan tanda, yakni + dan - yang didapat dari selisih pengamatan. Hasil pengamatan $\mathrm{x}$ dan y masing-masing terjadi karena perlakuan A dan B. Adapun bentuk rumus selisih (Sudjana, 2005:448) tersebut $\left(x_{i}-y_{i}\right)$. Jika $x_{i}>y_{i}$ maka diberi tanda + (positif), dan jika $\mathrm{x}_{\mathrm{i}}<\mathrm{y}_{\mathrm{i}}$ maka diberi tanda (negatif). Supaya pengujian dapat ditentukan hasilnya, maka diperlukan paling sedikit $\mathrm{n}=6$.

Jika rumusan Ha berbunyi kalimat: tidak sama dengan $(\neq)$, maka Ho berbunyi kalimat: sama dengan $(=)$. Pengujian ini menggunakan uji dua pihak yang bersifat asosiatif. Dalam penelitian ini penulis merumuskan hipotesis model statistik.

\section{HASIL DAN PEMBAHASAN}

Berdasarkan kajian teori yang mencakup model pembelajaran berdasarkan masalah, penataan sanggul up style dan hasil belajar mahasiswa maka peneliti menentukan variabel- variabel dalam penelitian ini, yakni (1) model pembelajaran berdasarkan masalah sebagai variabel bebas, (2) pengelolaan kelas, aktivitas mahasiswa, respon mahasiswa dan hasil belajar mahasiswa sebagai variabel terikat, (3) guru, mahasiswa dan jenis penataan sanggul up style sebagai variabel kontrol.
Berdasarkan paparan di atas maka deskripsi hasil implementasi pengembangan perangkatan akan dijelaskan sebagai berikut:

Efektivitas perangkat pembelajaran yang dikembangkan ditinjau berdasarkan pada hasil pelaksanaan pembelajaran menggunakan perangkat pembelajaran sanggul up style. Penerapan perangkat pembelajaran dilaksanakan pada bulan Maret dengan tiga kali tatap pertemuan, perangkat pembelajaran yang dikembangkan dalam penelitian ini diukur melalui empat indikator, yakti kemampuan guru mengelola kelas atau keterlaksanaan fase pembelajaran berbasis masalah, aktivitas mahasiswa, respon mahasiswa, serta hasil belajar mahasiswa yang dilihat sebelum dan sesudah menggunakan perangkat pembelajaran sanggul up style.

Pelaksanaan fase pembelajaran merupakan kemampuan guru dalam mengelola pembelajaran dengan menggunakan perangkat pembelajaran sanggul up style. Disini guru yang dimaksud adalah peneliti. Data tentang pengelolaan kelas diperoleh dari dua pengamat pada saat pembelajaran. Pengamat tersebut adalah guru pengampu mata pembelajaran sanggul up style. Berdasarkan hasil analisis dan data pembahasan, simpulan yang dapat diambil bahwa skor pengelolaan kelas atau keterlaksanaan fase pembelajaran pada pertemuan pertama sebesar 7,25. Skor pertemuan kedua adalah sebesar 7,4 dan skor pertemuan ketiga sebesar 7,52 dengan indeks rata-rata baik, artinya RPP yang dikembangkan dapat diaplikasikan dalam pembelajaran.

Aktivitas mahasiswa yang diamati adalah aktivitas mahasiswa pada pertemuan pertama, kedua dan ketiga. Untuk mengamati aktivitas mahasiswa selama kegitan pembelajaran, pengamat mencatat setiap kategori aktivitas mahasiswa yang terlaksana. Rerata aktivitas mahasiswa pada pertemuan pertama sebesar 69,58 dan pertemuan kedua sebesar 77,5 serta pertemuan ketiga sebesar 86,75, dengan indeks rerata sebesar 77,95 yang masuk dalam kategori baik, artinya mahasiswa sangat antusias dan tertarik dengan perangkat pembelajaran yang dikembangkan.

Kegiatan selanjutnya adalah angket respon mahasiswa. Angket respon mahasiswa diberkan setelah pembelajaran sanggul up style. Angket respon diberikan kepada mahasiswa untuk mengetahui tanggapan mahasiswa terhadap perangkat pembelajaran yang dikembangkan. Berdasarkan analisis data dan hasil pembahasan, mahasiswa yang memberikan respon ya terhadap perangkat pembelajaran sanggul up style sebesar 279 dengan rerata persentase respon mahasiswa sebesar 73,80. Respon positif yang diberikan mahasiswa berkaitan dengan seluruh aspek perangkat 
pembelajaran. Respon positif mahasiswa dalam hal ini menegaskan bahwa mahasiswa sangat tertarik pada perangkat pembelajaran yang dikembangkan.

Tes belajar mahasiswa digunakan untuk mengetahui keberhasilan proses pembelajaran menggunakan perangkat pembelajaran sanggul $u p$ style yang dikembangkan. Tes hasil belajar dilakukan dua kali setiap pertemuan, yakni tes untuk mengetahui kemampuan awal mahasiswa sebelum menggunakan perangkat pembelajaran (pre-test) dan tes akhir yang dilakukan setelah menggunakan perangkat pembelajaran (post-test). Berdasarkan analisi data dan hasil pembahasan, rata-rata hasil belajar mahasiswa sebesar 79,9 dan termasuk dalam kategori baik atau tuntas karena nilai mahasiswa diatas 61-68 (Riduwan, 2006:88).

Berdasarkan analisis di atas, keempat indikator pengembangan perangkat pembelajaran secara keseluruhan berkategori baik sehingga di peroleh hipotesis perangkat pembelajaran yang valid dan reliabel dapat meningkatkan hasil belajar mahasiswa dalam menata sanggul up style.

\section{KESIMPULAN}

Berdasarkan tujuan penelitian, hasil analisis data dan pembahasan hasil penelitian mengenai pengembangan perangkat pembelajaran penataan sanggul up style yang berdasarkan pada model pembelajaran berbasis masalah (PBM), dapat disimpulan bahwa proses pengembangan perangkat pembelajaran sanggul up style ini mengacu pada model 4-D menurut Thiagarajan, Semmel dan Semmel. Perangkat pembelajaran meliputi Rencana Pelaksanaan Pembelajaran (RPP), Lembar Kegiatan Mahasiswa (LKS), dan Modul Mahasiswa. Berdasarkan analisis dan hasil pengamatan, perangkat pembelajaran sanggul up style yang diterapkan memperoleh hasil sebagai berikut:

a. Pengelolaan kelas yang dilakukan oleh guru adalah sebanyak tiga kali pertemuan. Pertemuan pertama diperoleh skor sebesar 7,25. Pertemuan kedua diperoleh skor sebesar 7,38 dan pertemuan ketiga diperoleh skor sebesar 7,52. Rerata skor penilaian diperoleh skor sebesar 7,37 dengan kategori baik, artinya guru mampu mengelola kelas sesuai fase-fase dalam pembelajaran berdasarkan masalah.

b. Aktivitas mahasiswa diamati sebanyak tiga kali pertemuan. Pertemuan pertama diperoleh skor sebesar 69,58. Pertemuan kedua diperoleh skor sebesar 77,5 dan pertemuan ketiga diperoleh skor sebesar 86,75. Rerata indeks pertemuan diperoleh skor sebesar 77,94 dengan kategori baik, artinya mahasiswa antusias menerima pembelajaran dengan model berdasarkan masalah .

c. Persentase respon positif yang diberikan mahasiswa sebesar $73,80 \%$, hal ini menegaskan bahwa mahasiswa tertarik dengan perangkat pembelajaran sanggul up style yang dikembangkan.

d. Rata-rata hasil belajar mahasiswa adalah sebesar 79,9 dan dikatakan tuntas, artinya proses pembelajaran dengan perangkat pembelajaran sanggul up style adalah efektif untuk meningkatkan hasil belajar mahasiswa.

Dari hasil di atas maka dapat ditarik kesimpulan bahwa perangkat pembelajaran yang valid dan reliabel dapat meningkatkan hasil belajar mahasiswa dalam menata sanggul up style. Berdasarkan kesimpulan di atas, disampaikan beberapa saran sebagai berikut:

1. Pembelajaran sanggul up style menggunakan perangkat pembelajaran yang dikembangkan dapat menambah wawasan mahasiswa tentang teknik pembuatan sanggul up style, maka dari itu guru perlu mencoba model pembelajaran berdasarkan masalah sebagai alternative pembelajaran pada kompetensi dasar yang lain.

2. Melihat respon mahasiswa yang positif maka perlu dikembangkan perangkat pembelajaran yang berorientasi pada model pembelajaran berdasarkan masalah pada materi lain.

\section{REFERENSI}

Arikunto, Suharsimi. 2008. Dasar - dasar Evaluasi Pendidikan. Jakarta : Bumi Aksara.

Arikunto, Suharsimi. 2006. Prosedur penelitian suatu pendekatan praktik. Jakarta : PT Rineka Cipta

Depdiknas, 2006. KTSP dan Silabus SMK. Jakarta: Depdiknas

Harahap, Suhartini,dkk. 2002. Tata Kecantikan Rambut Terampil. Jakarta : Meutia Cipta Sarana.

Ibrahim, Muslimin. 2005. Pembelajaran Berdasarkan Masalah. Surabaya : UNESA University Press.

Kusumadewi, dkk. 1999. Pengetahuan dan Seni Tata Rambut Modern Tingkat Mahir. Jakarta Selatan : PT Carina Indah Utama.

Kusuma, W, Hapsari. 2004. Modul penataan sanggul modern pola back style.: Depdiknas. 
2004. Modul penataan sanggul modern pola front style : Depdiknas.

Mudjiono dan Dimyati.2002. Belajar dan Pembelajaran. Jakarta: Rineka Cipta

Mulyasa, E. 2006. Kurikulum Tingkat Satuan Pendidikan. Bandung : PT Remaja Rosdakarya.

Nursalim, Mochamad, dkk. 2007. Psikologi Pendidikan. Surabaya : UNESA University Press.

Nur, Muhammad \& Wikandari, 2008, Pengajaran Berpusat pada Mahasiswa dan Pendekatan Konstruktivis Dalam Pengajaran, Surabaya, Pusat Sains dan Matematika sekolah Unesa

Riduwan. 2006. Metode dan Teknik Menyusun Tesis. Bandung : ALFABETA.

Riduwan. 2009.Variable PengukuranPenelitian. Bandung : ALFABETA.

Riduwan. 2009. Skala Pengukuran Variabel variabel Penelitian. Bandung : ALFABETA.

Rostamailis, dkk. 2009. Tata Kecantikan Rambut Jilid 2. Direktorat Pembinaan Sekolah Menengah Kejuruan.

Santoso, Gempur. 2007. Metodologi penelitian kuantitatif dan kualitatif. Jakarta : Bumi Aksara.

Slameto.2003. Belajar dan faktor - faktor yang mempengaruhinya. Jakarta : PT RINEKA CIPTA.

Sudjana. 2005. Metoda statistika. Bandung : TARSITO.

Sudjana, Nana. 2006. Penilaian hasil proses belajar mengajar. Bandung : PT Remaja Rosdakarya.

Sudjana, Nana. 2009. Penilaian hasil proses belajar mengajar. Bandung : PT Remaja Rosdakarya. .1989. Cara belajar mahasiswa aktif dalam proses belajar mengajar. Bandung : Penerbit Sinar Baru.

Sugiyono. 2009. Statistika untuk penelitian. Bandung : ALFABETA.

Sutrisno, Joko. 2008. Teknis penyusunan RPP pada sekolah menengah kejuruan. Jakarta : Depdiknas.

Trianto, 2007, Model Pembelajaran Terpadu Dalam Teori dan Praktek Jakarta: Prestasi Pustaka.

Trianto, 2007. Model-model Pembelajaran Inovatif Berorientasi Konstruktivistik. Jakarta: Prestasi Pustaka.

Trianto. 2009. Mendesain model pembelajaran inovatif progresif. Jakarta : Kencana Prenada Media Group.
Thiagarajan, Semmel, D.S dan Semmel, M.I (1974). Intrucional Development for Training Teachers of Exceptional Children. Minnesota: University of Minnesota.

Wirjokusumo, Iskandar, dkk. 2009. Pengantar metode penelitian kuantitatif. Surabaya : UNESA University Press. 